\title{
High-Voltage Pulses Potentiate Bleomycin Cytotoxicity Towards Cancer Cells in vitro
}

\author{
R. Saulè, G. Saulis* And D. BatiušKaité \\ Vytautas Magnus University, 58 K. Donelaičio str., Kaunas, Lithuania
}

\begin{abstract}
In this study the influence of high-voltage pulses on bleomycin cytotoxicity towards mouse hepatoma MH-22A and rat glioma C6 cells in vitro was determined. It was obtained that combining bleomycin with pulses of strong electric field significantly enhances the number of cells killed by bleomycin. Bleomycin alone was cytotoxic to both cell lines at concentrations above $1 \mu \mathrm{M}$. Treatment of cells by electric pulses in the presence of bleomycin greatly potentiated its cytotoxicity towards both cell lines tested - the bleomycin concentration required to reduce cell survival by 50\% was 3.5-3.8 nM only. Exposure of cells to electric pulses only did not reduce cell viability.
\end{abstract}

PACS numbers: 87.50.cj, 87.80.Fe, 87.50.cf

\section{Introduction}

Hepatocellular carcinoma (HCC) is one of the most common malignant tumors worldwide with an estimated $0.5-1$ million new cases annually around the world $[1,2]$. So far, the only curative therapy options are liver resection or orthotopic liver transplantation [3]. Unfortunately, most patients (80\%) are inoperable and hepatoma cells are resistant to conventional chemotherapeutic approaches [4]. Similar situation is with malignant glioma. It is the most common primary central nervous system (CNS) tumour but radical tumor resection is impossible, while the efficiencies of radiotherapy and chemotherapy are unsatisfactory [5]. To reduce the morbidity and mortality of HCC and glioma, the development of novel therapies for advanced diseases is of paramount importance [6].

One of such therapies might be electrochemotherapy which is a combination of chemotherapy and a transient permeabilization of the cell membrane with pulses of strong electric field (electroporation) facilitating the entry of anti-cancer drugs directly into the cytosol [7]. It is a rather new approach for cancer therapy and, despite that the clinical trials have already been carried out in several countries the procedures are not optimized yet. Here, electrochemotherapy studies have been carried out in vitro with mouse hepatoma $\mathrm{MH}-22 \mathrm{~A}$ and rat glioma C6 cells.

\section{Materials and methods}

Experiments were performed in vitro with two tumor cell lines: mouse hepatoma $\mathrm{MH}-22 \mathrm{~A}$ and rat glioma C6

\footnotetext{
* corresponding author; e-mail: g.saulis@gmf.vdu.lt
}

cells. The cells were grown in monolayer cultures in $60 \mathrm{ml}$ flasks at $37^{\circ} \mathrm{C}$ and $5 \% \mathrm{CO}_{2}$ in water-jacketed incubator IR AutoFlow NU-2500E (NuAire, Plymouth, MN, USA). When cells reached confluence they were trypsinazed for 2 to $10 \mathrm{~min}$ with $2 \mathrm{ml}$ of $0.25 \%$ trypsin- $0.02 \%$ ethylenediaminetetraacetic acid (EDTA) solution (cat. no. T4049, Sigma-Aldrich Chemie). When cells detached from the flask bottom, cell suspension was supplemented with $2 \mathrm{ml}$ culture medium. After centrifugation of the suspension for $5 \mathrm{~min}$ at $1000 \mathrm{rpm}$, cells were resuspended in a minimum essential medium Eagle at a concentration of approximately $1 \times 10^{6}$ cells $/ \mathrm{ml}$. Then $45 \mu \mathrm{l}$ of the cell suspension was mixed with $5 \mu \mathrm{l}$ of bleomycin solution, placed between two stainless-steel electrodes $2 \mathrm{~mm}$ apart, and subjected to a single square-wave electric pulse with the duration of 0.1 or $1 \mathrm{~ms}$ and the amplitude ranging from 0.2 to $2.4 \mathrm{kV} / \mathrm{cm}$.

After the exposure to an electric pulse, the cells were incubated for $20 \mathrm{~min}$ at room temperature. Then the cell suspension was diluted with $1.56 \mathrm{ml}$ of a minimum essential medium Eagle $\left(37^{\circ} \mathrm{C}\right)$ and after an additional incubation for $10 \mathrm{~min}$ at $37^{\circ} \mathrm{C}$, cells were seeded in duplicate $(\approx 300$ cells $/ 35 \mathrm{~mm}$ diameter Petri dish). All manipulations that required sterile conditions were done in a vertical laminar flow cabinet (Aura Vertical SD4, BIOAIR Instruments, Siziano, Italy). The cells in Petri dishes were incubated at $37^{\circ} \mathrm{C}$ and $5 \% \mathrm{CO}_{2}$ in the incubator for 6 (rat glioma C6) or 10 (mouse hepatoma MH-22A) days.

The efficiency of the exposure to bleomycin as well as cell sensitivity to combined treatment with bleomycin and electric pulses were estimated from the reduction of the cell viability. The cell viability was determined by means of a colony-forming assay [8]. After 6 or 10 days, the colonies were fixed with $96 \%$ ethanol, stained with a Gram's crystal violet solution (Fluka Chemie, Buchs, 
Germany), and counted under a binocular light microscope. The cell viability was calculated as the percentage of the colonies obtained from the untreated control cells $[9]$.

\section{Results and discussion}

To study the action of bleomycin on electroporated cells and the action of various factors on its efficiency it is necessary to find such an electric treatment when a large fraction of cells becomes permeable to bleomycin but, at the same time, only a small fraction of cells is killed by an electric treatment. So, at the beginning, the dependence of the fraction of cells the membranes of which have became permeable to bleomycin and the fraction of cells that were killed by exposure to a single square-wave electric pulse on the pulse amplitude were determined. These relationships obtained for mouse hepatoma $\mathrm{MH}-22 \mathrm{~A}$ cells exposed to a pulse with the duration of $100 \mu \mathrm{s}$ are shown in Fig. 1. The same relationships were also obtained for rat glioma C6 cells exposed to a square-wave electric pulse with the duration of $1 \mathrm{~ms}$ (data not shown).

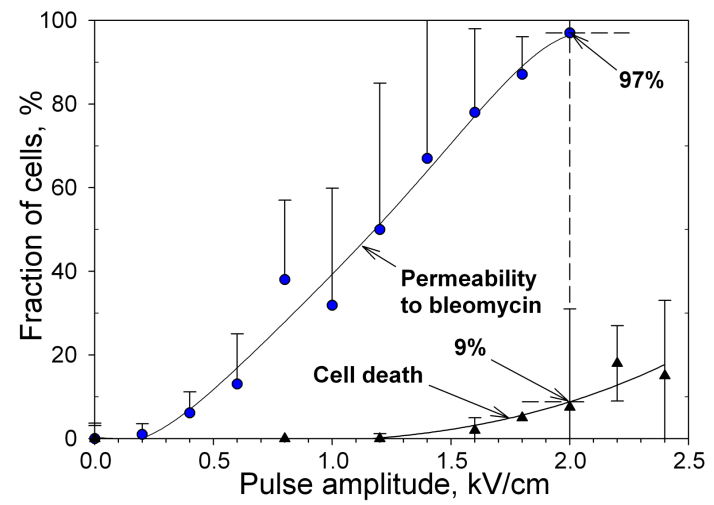

Fig. 1. Dependences of the fraction of mouse hepatoma MH-22A cells the plasma membrane of which

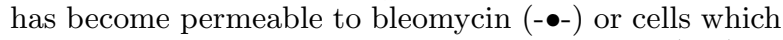
died due to the action of an electric pulse alone (- $\mathbf{\Delta -})$ on the amplitude of a square-wave electric pulse with the duration of $100 \mu \mathrm{s}$.

It can be seen from Fig. 1 that pores permeable to bleomycin appeared in the cell plasma membrane at electric field intensities higher than $0.3-0.4 \mathrm{kV} / \mathrm{cm}$, and that with increasing pulse intensity there is an increase in the number of cells permeable to bleomycin. The cells that were killed just by the exposure by an electric pulse appeared at electric field intensities higher than $1.5 \mathrm{kV} / \mathrm{cm}$ (Fig. 1). For an electric pulse with the amplitude of $2.0 \mathrm{kV} / \mathrm{cm}$, the plasma membranes of almost all cells $(\approx 97 \%$ ) became permeable to bleomycin but only a small fraction of cells $(\approx 9 \%)$ died due to the action of an electric pulse alone. Such pulses $(2.0 \mathrm{kV} / \mathrm{cm}, 100 \mu \mathrm{s})$ were used for subsequent studies on the influence of electric pulses on the efficiency of bleomycin cytotoxicity on mouse hepatoma cells. In the subsequent experiments with rat glioma cells the electric pulses with amplitude of $0.8 \mathrm{kV} / \mathrm{cm}$ and the duration of $1 \mathrm{~ms}$ were used.

The influence of an electric pulse on the cytotoxic efficiency of bleomycin was estimated from the reduction of cell viability after exposure to bleomycin alone and in combination with electric pulses. Cell viability was determined by means of a colony-forming assay [8]. The dependences of the viability of intact cells and cells exposed to an electric pulse on the concentration of bleomycin obtained for mouse hepatoma $\mathrm{MH}-22 \mathrm{~A}$ and rat glioma $\mathrm{C} 6$ cells are shown in Fig. 2.
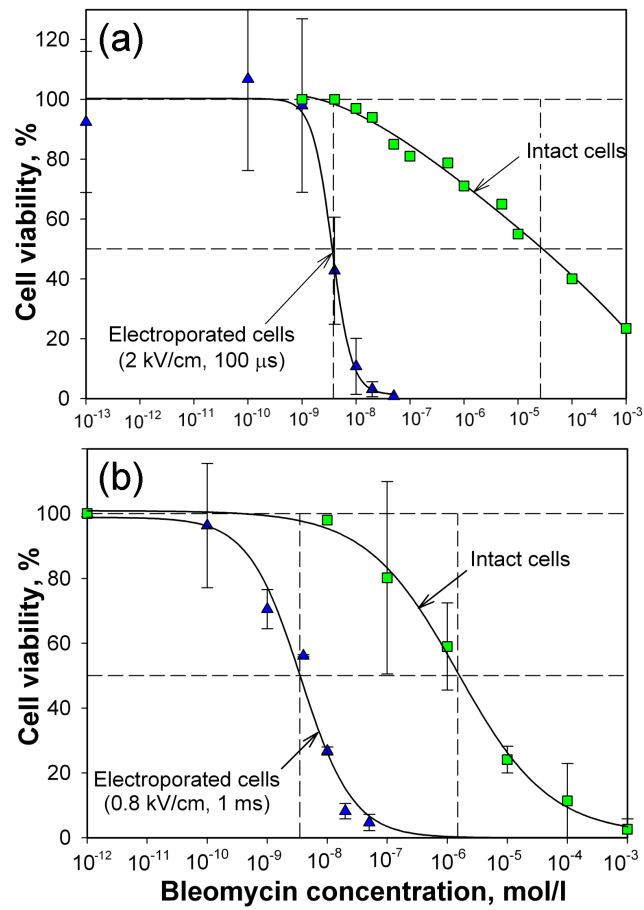

Fig. 2. The dependences of the viability of intact cells $(-\square-)$ and cells exposed to an electric pulse (- $\left.\mathbf{\Delta}^{-}\right)$on the concentration of bleomycin obtained for mouse hepatoma MH-22A (up) and rat glioma C6 (down) cells.

It can be seen from Fig. 2 that bleomycin alone is cytotoxic for cells in concentrations above 10-20 nM. To reduce the viability of mouse hepatoma $\mathrm{MH}-22 \mathrm{~A}$ and rat glioma C6 cells high concentrations of bleomycin are required (26 and $1.5 \mu \mathrm{M}$, respectively). Recall that an electric pulse alone is not cytotoxic to these cancer cell lines. Meanwhile, permeabilization of the cell plasma membrane to bleomycin by exposure of them to a square-wave electric pulse significantly increases the cytotoxic activity of bleomycin in the case of both cancer cell lines tested. To reduce the cell viability by $50 \%$ much lower concentrations of bleomycin were required -3.8 and $3.5 \mathrm{nM}$ for mouse hepatoma $\mathrm{MH}-22 \mathrm{~A}$ and rat glioma $\mathrm{C} 6$ cells, respectively. 


\section{Conclusions}

It can be concluded that combining bleomycin with pulses of strong electric field significantly enhances the number of cells killed by bleomycin. Neither bleomycin at concentrations lower than $50 \mathrm{nM}$, nor electric pulse alone was cytotoxic to both cancer cell lines. Treatment of cells by electric pulses in the presence of bleomycin greatly potentiated its cytotoxicity towards both cancer cell lines tested - the bleomycin concentration required to reduce cell survival by $50 \%$ was reduced from $1.5-26 \mu \mathrm{M}$ to $3.5-3.8 \mathrm{nM}$, i.e., $430-6800$ times.

\section{Acknowledgments}

The work was in part supported by grant T-57/06 from the Lithuanian Science and Studies Foundation.

\section{References}

[1] D. Motola-Kuba, D. Zamora-Valdes, M. Uribe, N. Mendez-Sanchez, Ann. Hepatol. 5, 16 (2006).
[2] M. Ocker, C. Herold, M. Ganslmayer, S. Zopf, E.G. Hahn, D. Schuppan, Cancer Lett. 208, 51 (2004).

[3] J. Figueras, E. Jaurrieta, C. Valls, E. Ramos, T. Serrano, A. Rafecas, J. Fabregat, J. Torras, J. Am. Coll. Surg. 190, 580 (2000).

[4] C. Herold, T. Reck, P. Fischer, R. Ott, M. Radespiel-Troeger, M. Ganslmayer, W. Hohenberger, E.G. Hahn, D. Schuppan, Liver 22, 23 (2002).

[5] K. Skauminas, L. Klumbys, J. Dididkis, V. Jadkevičienë, V. Daferis, Neurologijos seminarai $\mathbf{5 8}$ (2003).

[6] H.E. Blum, World J. Gastroenterol. 11, 7391 (2005).

[7] A. Gothelf, L.M. Mir, J. Gehl, Cancer Treat Rev. 29, 371 (2003).

[8] Culture of Animal Cells: A Manual of Basic Techniques,Ed. I.R. Freshney, 4th ed., Wiley, New York 2000.

[9] G. Saulis, S. Satkauskas, R. Praneviciute, Anal. Biochem. 360, 273 (2007). 